\title{
Dampak Penerapan Agreement On The Application Of Sanitary And Phytosanitary Measures Terhadap Perdagangan Di Indonesia
}

\author{
Fahmi Fairuzzaman \\ Magister Ilmu Hukum Fakultas Hukum Universitas Islam Indonesia \\ Jln. Cikditiro No. 1 Yogyakarta \\ fahmi.fairuzzaman@gmail.com
}

\begin{abstract}
The problem in this research is whether the SPS Agreement actually becomes a barrier in trade? And what is the impact of the SPS Agreement on trade in Indonesia? The research method used is Normative Juridical. The results of the study concluded, first, the existence of the SPS Agreement can be a barrier to trade, but it is an obstacle that is excluded as long as it is done in accordance with the provisions contained in the SPS Agreement. Second, the existence of the SPS Agreement allows Indonesia to implement regulations that better protect its citizens from health risks that may arise from the import of certain products, especially food. These rules must still be in line with the SPS Agreement.
\end{abstract}

Keywords: Trade barrier; SPS agreement; WTO

\begin{abstract}
Abstrak
Permasalahan dalam penelitian ini, apakah dengan adanya SPS Agreement justru menjadi hambatan dalam perdagangan? Serta bagaimanakah dampak SPS Agreement terhadap perdagangan di Indonesia? Metode penelitian yang digunakan adalah Yuridis Normatif. Hasil penelitian menyimpulkan, pertama, adanya SPS Agreement dapat menjadi hambatan bagi perdagangan, akan tetapi hal tersebut merupakan hambatan yang dikecualikan dengan catatan harus sesuai dengan ketentuan yang terdapat didalam SPS Agreement. Kedua, adanya SPS Agreement membuat Indonesia dapat menerapkan aturan yang lebih melindungi warganya dari resiko kesehatan yang mungkin timbul dari adanya impor produk tertentu terutama makanan. Aturan tersebut tetap harus sejalan dengan SPS Agreement.
\end{abstract}

Kata-kata Kunci: Hambatan perdagangan; SPS agreement; WTO 


\section{Pendahuluan}

Suatu negara tidak dapat hanya bergantung pada sumber daya yang mereka miliki sendiri mengingat terbatasnya sumber daya yang ada di dalam negara tersebut. Dengan keterbatasan sumber daya, tidak mungkin suatu negara mampu memenuhi kebutuhannya sendiri. Oleh karena itu, diperlukan adanya perdagangan yang melintasi batas antar negara, atau yang biasa disebut perdagangan internasional, untuk memenuhi kebutuhan-kebutuhan tersebut. Selain untuk memenuhi kebutuhan-kebutuhan di dalam negeri, perdagangan internasional juga dapat bermanfaat bagi pembangunan ekonomi suatu negara dengan cara memasarkan produk dalam negeri ke negara-negara lain sehingga memperoleh suatu keuntungan.

Perdagangan dengan melintasi batas negara tersebut berarti juga mempertemukan kepentingan-kepentingan antara negara yang terlibat. Agar kepentingan masing-masing negara dan kewajiban serta hak yang timbul di dalamnya tetap dapat terjaga, maka diperlukan suatu peraturan atau hukum yang mengatur kegiatan perdagangan internasional tersebut. Instrumen hukum yang digunakan untuk mengatur perdagangan internasional adalah hukum internasional. Secara spesifik hukum internasional yang digunakan adalah perjanjian internasional yang mengikat pihak-pihak yang terlibat dalam perdagangan internasional tersebut.

Menurut Atip Latifulhayat sebagaimana dikutip oleh Muh. Risnain, walaupun perdagangan internasional dalam praktiknya terjadi antara perusahaan maupun individu yang ada di masing-masing negara, namun yang membentuk hukum dan terikat pada hukum internasional adalah negara. Untuk itu yang memiliki tanggung jawab dalam hukum internasional adalah negara, bukan individu secara langsung. ${ }^{1}$ Indonesia termasuk dalam salah satu dari negaranegara yang terlibat di dalamnya. Perdagangan internasional digunakan oleh Indonesia untuk memenuhi kebutuhan dalam negerinya sekaligus untuk memasarkan produk-produknya ke negara-negara lain. Oleh karena itu, agar dapat

${ }^{1}$ Atip Latifulhayat, The Urgent Need for and Models of participation of Private parties in Claims before the World Trade Organization, Dikutip dari Muh. Risnain, "Politik Hukum Perlindungan Industri dalam Negeri Indonesia dalam Menghadapi Perdagangan Bebas", Fiat Justisia Jurnal Ilmu Hukum, Vol. 5 No. 3, hlm. 277. 
melakukan perdagangan internasional Indonesia juga terlibat dalam berbagai perjanjian internasional di bidang perdagangan internasional. Perjanjian internasional dilakukan oleh Indonesia dalam beberapa bentuk, yaitu perjanjian bilateral atau antara dua negara, regional atau antar negara dalam satu kawasan, dan multilateral atau antara beberapa negara.

Salah satu contoh perjanjian internasional di mana Indonesia menjadi pihak di dalamnya adalah Perjanjian Pembentukan Organisasi Perdagangan Dunia (WTO). Indonesia melalui Undang-Undang Nomor 7 Tahun 1994 tanggal 2 November 1994 tentang Pengesahan (ratifikasi) "Agreement Establising the World Trade Organization", telah melakukan ratifikasi atas pembentukan WTO yang disepakati dalam Putaran Uruguay. Persetujuan-persetujuan multilateral yang dihasilkan Putaran Uruguay tersebu terdiri dari multilateral trade agreements dan plurilateral trade agreements. Persetujuan-persetujuan tersebut merupakan hasil perundingan atas 15 subyek Putaran Uruguay yang menyangkut masalah Tariff, Non-Tariff Measures, Tropical Products, Natural Resource-Based Products, Textiles and Clothing, Agriculture, GATT Articles, MTN Agreements and Arrangements, Subsidies and Countervailing Measures, Dispute Settlement, Trade Related Aspects of Intellectual Property Rights (TRIPS) including trade in counterfeit goods, Trade Related Investment Measures (TRIMs), Functioning of the GATT system (FOGs), Safeguard, dan Trade in Services. ${ }^{2}$ Indonesia, sebagai pihak dalam perjanjian tersebut, otomatis menjadi anggota dari WTO dan harus mengikuti peraturan-peraturan yang ada di dalamnya. WTO menerapkan suatu sistem perdagangan yang bebas (free trade) antara negara-negara anggotanya. Perdagangan bebas menghendaki agar setiap negara yang terlibat di dalamnya dapat mengurangi hambatan-hambatan yang ada, baik hambatan tarif maupun non-tarif, dalam proses perdagangan agar tercipta persaingan yang adil antara negara-negara yang melakukan aktivitas perdagangan tersebut.

Terdapat satu peraturan dalam WTO yang menarik untuk dikaji, yaitu Agreement on the Application of Sanitary and Phytosanitary Measures atau biasa disebut

\footnotetext{
${ }^{2}$ Eko Prilianto Sudradjat, "Penerapan WTO Agreement on the Application of Sanitary and Phytosanitary Measures: Analisis Tentang Penerapan Public Health Security And Bioterrorism Preparedness And Response Act Of 2002 oleh Amerika Serikat”, Jendela Informasi Hukum Bidang Perdagangan, Desember 2012, hlm 9.
} 
SPS Agreement. Awalnya aturan tersebut termasuk di dalam Agreement on Agriculture. Adanya peraturan tersebut karena dengan semakin berkembangnya dunia perdagangan internasional, terutama di bidang pertanian, maka semakin meningkatkan resiko kesehatan yang menyertainya juga. Bidang pertanian yang dimaksud disini bukan hanya mengenai tumbuhan, tetapi didalamnya juga termasuk hewan. SPS Agreement bertujuan untuk melindungi kesehatan, keselamatan ataupun untuk perlindungan lingkungan. ${ }^{3}$

Aspek kesehatan dari SPS Agreement pada dasarnya berarti bahwa anggota WTO dapat melindungi kehidupan manusia, hewan, dan tumbuhan dengan menerapkan ketentuan-ketentuan untuk mengelola risiko yang berhubungan dengan impor. Ketentuan tersebut biasanya dalam bentuk persyaratan karantina atau keamanan pangan. Ketentuan yang dapat diterapkan oleh anggota WTO diklasifikasikan sebagai dua kategori, yaitu sanitasi (terkait dengan kehidupan atau kesehatan manusia atau hewan) atau fitosanitasi (terkait dengan kehidupan atau kesehatan tumbuhan). ${ }^{4}$

Terkait dengan aspek perdagangan internasional, secara prinsip berarti bahwa dalam usaha melindungi kesehatan, anggota WTO tidak seharusnya menggunakan ketentuan SPS yang tidak diperlukan, tidak berdasarkan pada pertimbangan ilmiah, mengada-ada, atau secara tersembunyi (tersamar) membatasi perdagangan internasional. ${ }^{5}$ Para negara anggota WTO sering mengadopsi SPS Agreement untuk melindungi manusia dan hewan dari resiko kemanan pangan, atau untuk melindungi manusia, hewan dan tumbuhan dari risiko-risiko yang timbul dari hama dan penyakit. Akan tetapi, negara-negara pengekspor produk makanan dan pertanian, dan juga organisasi-organisasi internasional, telah mengamati bahwa SPS Agreement semakin meningkat penggunaannya sebagai alat proteksi dalam perdagangan. ${ }^{6}$ Proteksi tersebut terselubung dalam bentuk hambatan non-tarif. Hambatan tersebut

\footnotetext{
${ }^{3}$ Sri Wartini, "Implementasi Prinsip Kehati-hatian dalam Sanitary and Phythosanitary Agreemant, Studi Kasus: Keputusan Appellate Body WTO Dalam Kasus Hormone Beef Antara Uni Eropa Dengan Amerika Serikat", Jurnal Hukum, Vol. 14 No. 2, 2007, hlm. 296.

4 Departemen Pertanian, Perikanan, dan Kehutanan Australia, "Kesepakatan Organisasi Perdagangan Dunia (WTO) tentang Sanitari dan Fitosanitari”, http://www.agriculture.gov.au/SiteCollectionDocuments/ languages/indonesian/piaph/sps_booklet_bahasa.pd f, diakses pada 24 Juli 2017, hlm. 3.

${ }^{5}$ Ibid.

${ }^{6}$ Peter Van den Bossche dan Werner Zdouc, The Law and Policy of the World Trade Organization: Text, Cases and Material, Cambridge University Press, Cambridge, 2017, hlm. 936.
} 
bersifat teknis seperti alasan kesehatan, pengepakan, labelling yang kadang-kadang disamarkan sehingga tidak terlihat sebagai hambatan perdagangan.7

Indonesia pernah setidaknya dua kali berperkara di WTO terkait dengan SPS Agreement. Akan tetapi, sejauh ini Indonesia selalu menjadi pihak yang digugat dan belum pernah menggugat negara anggota lain terkait dengan SPS Agreement. Dua kasus di WTO yang melibatkan Indonesia terkait dengan SPS Agreement tersebut adalah kasus nomor DS484 dan DS506. Kasus yang pertama, yaitu DS484 berjudul "Indonesia - Measures Concerning the Importation of Chicken Meat and Chicken Products". Kasus tersebut diajukan ke WTO oleh Brazil selaku pihak penggugat terhadap Indonesia selaku pihak tergugat.

Brazil menganggap kebijakan importasi yang diberlakukan Indonesia merupakan upaya proteksi perdagangan. Padahal bagi Indonesia, kebijakan itu merupakan upaya perlindungan terhadap konsumen dalam negeri untuk mendapatkan produk yang aman, sehat, dan halal. Brazil menggugat secara keseluruhan dan beberapa ketentuan importasi secara khusus, yaitu daftar positif (positive list), persyaratan penggunaan, diskriminasi dalam persyaratan label halal, pembatasan transportasi impor, dan penundaan persetujuan persyaratan sanitasi. Brazil menganggap ketentuan dalam poin-poin rezim importasi tersebut menghambat ekspor Brazil ke Indonesia. Brazil menyatakan, sebagai eksportir ayam terbesar di dunia dan produsen serta eksportir ayam halal terbesar di dunia, akses pasarnya tertutup masuk ke Indonesia selama tujuh tahun sejak 2009. Namun, Indonesia menyampaikan bahwa saat ini standar halal setiap negara mungkin saja berbeda. ${ }^{8}$ Ada beberapa dasar hukum yang digunakan Brazil dalam gugatannya tersebut, namun terkait dengan SPS Agreement yang digunakan adalah Articles 2.2, 2.3, 3.1, 5, 5.1, 5.2, 5.5, 5.6, 8 dan Annex C of the SPS Agreement. Kasus ini sendiri telah sampai pada tahap sidang panel. ${ }^{9}$

${ }^{7}$ H.S. Kartadjoemena, GATT, WTO dan Hasil Uruguay Round, UI Press, Jakarta, 2007, hlm. 126.

8 Aprillia Ika, "Brasil Gugat Indonesia Terkait Syarat Importasi Daging dan Produk Ayam yang Halal", http://ekonomi.kompas.com/read/2016/10/15/100000826/brasil.gugat.indonesia.terkait.syarat.importasi.dag ing.dan.produk.ayam.yang.halal., diakses pada 24 Juli 2017.

${ }^{9}$ Dokumen Permohonan Konsultasi WTO No. WT/DS484/1, hlm. 3. 
Kasus yang kedua, yaitu DS506 berjudul "Indonesia - Measures Concerning the Importation of Bovine Meat". Kasus tersebut juga diajukan oleh Brazil sebagai pihak penggugat terhadap Indonesia selaku pihak tergugat. Mirip dengan kasus sebelumnya, tetapi kali ini terkait dengan daging sapi. Kasus ini baru sampai tahap konsultasi antara Brazil dengan Indonesia. Dokumen yang tersedia dalam situs WTO menunjukkan tahapan terakhir yang sedang dilalui adalah Indonesia menerima permintaan konsultasi yang diajukan Brazil. Dasar hukum terkait SPS Agreement yang digunakan Brazil dalam gugatannya adalah Articles 2.1, 2.2, 2.3, 3.1, 3.2, 3.3, 5.1, 5.2, 5.4, 5.6, 5.7, 6.1, 6.2, 6.3, 7, 8 dan Annex C of the SPS Agreement. ${ }^{10}$ Kedua kasus diatas menarik untuk dibahas, akan tetapi pada tulisan ini akan lebih difokuskan pada kasus yang pertama.

\section{Rumusan Masalah}

Berdasarkan uraian latar belakang di atas, untuk membatasi permasalahan yang akan dibahas dalam tulisan ini maka masalah dirumuskan sebagai berikut. Pertama, apakah dengan adanya SPS Agreement tersebut justru menjadi hambatan dalam perdagangan? Kedua, bagaimanakah dampak SPS Agreement terhadap perdagangan di Indonesia?

\section{Tujuan Penelitian}

Penelitian ini bertujuan untuk mengetahui sekaligus memahami adanya SPS Agreement merupakan suatu hambatan atau bukan suatu hambatan dalam perdagangan dalam kerangka WTO. Selain itu, penelitian ini juga bertujuan untuk mengetahui sekaligus memahami dampak dari adanya SPS Agreement terhadap perdagangan khususnya di Indonesia.

\section{Metode Penelitian}

Jenis penelitian yang digunakan adalah yuridis normatif, yaitu penelitian hukum yang mengonsepsikan hukum sebagai norma meliputi nilai-nilai, hukum positif dan putusan pengadilan, serta lebih difokuskan untuk mengkaji penerapan

${ }^{10}$ Dokumen Permohonan Konsultasi WTO No. WT/DS506/1, hlm. 3. 
kaidah-kaidah atau norma-norma dalam hukum positif.11 Pendekatan yang digunakan dalam penelitian ini adalah pendekatan Studi Kasus, yaitu melakukan telaah terhadap kasus-kasus yang berkaitan dengan masalah yang dihadapi. Sumber data yang diperlukan dalam penelitian ini adalah berupa Data Sekunder atau disebut juga Bahan Hukum, yaitu data yang diperoleh dari penelaahan kepustakaan. ${ }^{12}$ Bahan hukum yang digunakan adalah Bahan Hukum Primer meliputi perjanjian internasional, dokumen dari badan penyelesaian sengketa internasional, serta putusan pengadilan internasional yang berhubungan dengan kasus yang akan diteliti, serta Bahan Hukum Sekunder meliputi buku-buku dan jurnal-jurnal terkait dengan permasalahan yang diangkat dalam penelitian ini. Pengumpulan Bahan Hukum akan dilakukan dengan cara Studi Pustaka, kemudian data yang telah diperoleh tersebut diolah dan disajikan dengan cara deskriptif, yaitu menggambarkan secara menyeluruh tentang apa yang menjadi pokok permasalahan dalam penelitian ini.

\section{Hasil Penelitian dan Pembahasan}

Agreement on the Application of Sanitary and Phytosanitary Measures (SPS Agreement)

Telah diratifikasinya Perjanjian Pembentukan Organisasi Perdagangan Dunia (WTO) melalui Undang-Undang Nomor 7 Tahun 1994 tanggal 2 November 1994 tentang Pengesahan (ratifikasi) "Agreement Establising the World Trade Organization" menjadikan Indonesia sebagai salah satu negara anggota WTO. Menjadi anggota WTO berarti juga harus menyesuaikan aturan nasionalnya dengan ketentuan yang ada di WTO. Salah satu ketentuan yang diatur oleh WTO adalah Agreement on the Application of Sanitary and Phytosanitary Measures atau biasa disebut SPS Agreement. Adanya peraturan tersebut karena dengan semakin berkembangnya dunia perdagangan internasional, terutama di bidang pertanian, maka semakin meningkatkan resiko kesehatan yang menyertainya juga. Bidang pertanian yang

\footnotetext{
295.

${ }^{11}$ Johnny Ibrahim, Teori dan Metodologi Penelitian Hukum Normatif, Bayumedia Publishing, Malang, 2008, hlm.

12 Mukti Fajar dan Yulianto Achmad, Dualisme Penelitian Hukum: Normatif \& Empiris, Pustaka Pelajar, Yogyakarta, 2010), hlm. 156.
} 
dimaksud disini bukan hanya mengenai tumbuhan, tetapi di dalamnya juga termasuk hewan.

SPS Agreement pada intinya mengenai kesehatan dan perdagangan internasional. Perdagangan internasional dalam perjalanannya telah mengalami perluasan secara signifikan dalam kurun waktu 50 tahun terakhir. Hal ini berakibat meningkatnya perpindahan produk pertanian yang selanjutnya dapat meningkatkan risiko kesehatan. SPS Agreement memperkenalkan perlunya bagi negara anggota WTO untuk tidak hanya melindungi dari risiko yang disebabkan oleh masuknya hama, penyakit, dan gulma, tetapi juga untuk meminimalkan efek negatif dari ketentuan SPS terhadap perdagangan. ${ }^{13}$

Aspek kesehatan dari SPS Agreement pada dasarnya berarti bahwa anggota WTO dapat melindungi kehidupan manusia, hewan, dan tumbuhan dengan menerapkan ketentuan-ketentuan untuk mengelola risiko yang berhubungan dengan impor. Ketentuan tersebut biasanya dalam bentuk persyaratan karantina atau keamanan pangan. Ketentuan yang dapat diterapkan oleh anggota WTO diklasifikasikan sebagai dua kategori, yaitu sanitasi (terkait dengan kehidupan atau kesehatan manusia atau hewan) atau fitosanitasi (terkait dengan kehidupan atau kesehatan tumbuhan). Aspek kedua adalah aspek perdagangan internasional, secara prinsip berarti bahwa dalam usaha melindungi kesehatan, anggota WTO tidak seharusnya menggunakan ketentuan SPS yang tidak diperlukan, tidak berdasarkan pada pertimbangan ilmiah, mengada-ada, atau secara tersembunyi (tersamar) membatasi perdagangan internasional. ${ }^{14}$

SPS Agreement mempunyai 14 pasal, berisi tentang hak dan kewajiban yang telah disetujui oleh anggota WTO. Kesepakatan tersebut juga mempunyai tiga lampiran (annex) yang memuat definisi berbagai istilah, dan penjelasan dari beberapa kewajiban dalam batang tubuh SPS Agreement. ${ }^{15}$ Tindakan yang termasuk ke dalam Tindakan SPS meliputi sebagai berikut:16

a. Melindungi kehidupan atau kesehatan hewan atau tanaman dalam wilayah negara anggota dari risiko yang timbul dari masuknya, pembentukan atau

\footnotetext{
${ }^{13}$ Departemen Pertanian, Perikanan, dan Kehutanan Australia, Loc.Cit.

${ }^{14}$ Ibid.

${ }^{15}$ Departemen Pertanian, Perikanan, dan Kehutanan Australia, Op. Cit., hlm. 4.

${ }^{16}$ Kevin C. Kennedy, "Resolving International Sanitary and Phytosanitary Disputes in The WTO: Lessons and Future Directions", Food and Drug Law Journal, Vol. 55, 2000, hlm. 3.
} 
penyebaran hama, penyakit, organisme pembawa penyakit atau organisme penyebab penyakit;

b. Melindungi kehidupan atau kesehatan manusia atau hewan dalam wilayah negara anggota dari risiko yang timbul dari aditif, kontaminan (zat-zat yang mencemarkan), toksin atau organisme penyebab penyakit yang terkandung dalam makanan, minuman atau bahan pakan ternak;

c. Melindungi kehidupan dan kesehatan manusia dalam wilayah negara anggota dari risiko yang timbul dari penyakit yang dibawa hewan, tanaman atau produknya, atau dari masuknya, pembentukan atau penyebaran hama; atau

d. Mencegah atau membatasi kerugian lain dalam wilayah Anggota yang timbul dari masuknya, pembentukan atau penyebaran hama.

SPS Agreement berlaku untuk seluruh tindakan SPS yang memberikan dampak bagi perdagangan internasional. Pasal 2 ayat (1) SPS Agreement secara eksplisit mengakui adanya kebebasan hak dari negara anggota WTO untuk menerapkan tindakan SPS dalam rangka perlindungan terhadap kehidupan atau kesehatan manusia, binatang atau tumbuhan dalam wilayah mereka. Akan tetapi, bersamaan dengan itu, SPS Agreement juga memberikan kewajiban-kewajiban tertentu bagi para negara anggota yang ingin menerapkan tindakan SPS tersebut. ${ }^{17}$ Pasal tersebut sendiri berbunyi: "Members have the right to take sanitary and phytosanitary measures necessary for the protection of human, animal or plant life or health, provided that such measures are not inconsistent with the provisions of this Agreement" ${ }^{18}$ Terjemahan dari pasal tersebut adalah: "Para Anggota berhak untuk mengambil tindakan-tindakan yang perlu untuk melindungi kehidupan dan kesehatan manusia, hewan dan tanaman dengan ketentuan bahwa tindakan-tindakan itu tidak menyimpang dari ketentuan-ketentuan dalam perjanjian ini". ${ }^{19}$

Pasal tersebut menjadi batasan dari tindakan-tindakan SPS yang dapat diterapkan. Negara anggota WTO hanya dapat menerapkan tindakan SPS sepanjang diperlukan untuk melindungi kehidupan atau kesehatan manusia, binatang atau tumbuhan. Tindakan SPS harus didasarkan pada prinsip-prinsip

\footnotetext{
${ }^{17}$ Peter van den Bossche, Daniar Natakusumah dan Joseph Wira Koesnaidi., Pengantar Hukum WTO (World Trade Organization), Yayasan Obor Indonesia, Jakarta, 2010, hlm. 86.

18 Agreement on The Application of Sanitary and Phytosanitary Measures

${ }^{19}$ Eko Prilianto Sudradjat, Loc.Cit.
} 
ilmiah (scientific principles) dan tidak boleh dipertahankan tanpa adanya bukti ilmiah yang memadai. Negara anggota WTO tidak boleh mengenakan tindakan SPS yang mendiskriminasi secara sepihak (arbitrarily) atau tidak berdasar atau yang menyebabkan suatu hambatan terselubung terhadap perdagangan. ${ }^{20}$

Beberapa contoh dari tindakan SPS yang dapat dilaksanakan oleh para negara anggota WTO adalah:21

a. Menerapkan syarat hewan atau produk dengan bahan baku hewan yang diimpor harus dari wilayah yang bebas dari penyakit;

b. Inspeksi atau pemeriksaan kandungan racun mikrobiologi suatu produk yang diimpor;

c. Menginstruksikan tindakan fumigasi khusus untuk produk yang diimpor;

d. Mensyaratkan kadar pestisida yang dapat diterima di dalam makanan;

e. Larangan masuk produk yang mengandung bahan-bahan beracun yang membahayakan kesehatan manusia.

Hak untuk melakukan tindakan yang diperlukan untuk perlindungan, sebagaimana dimaksudkan di atas, merupakan pengecualian yang diberikan untuk penerapan prinsip Free Trade (Pasar Bebas) dari WTO untuk menghapus segala hambatan perdagangan internasional. Terkait dengan hal tersebut, tindakan perlindungan atas kesehatan warga negara, hewan dan tumbuhan didalam wilayah para negara anggota WTO merupakan salah satu hambatan perdagangan internasional. Akan tetapi, tindakan yang dilakukan dalam rangka penerapan SPS Agreement tersebut merupakan pengecualian dari penerapan hambatan berdasarkan GATT 1994 (General Agreement on Tariffs and Trade).22

SPS Agreement memang mendorong agar konsisten dengan standar internasional, namun juga memungkinkan para negara anggota untuk mempertahankan atau memperkenalkan tindakan-tindakan SPS dengan standar yang lebih tinggi sepanjang mereka dapat memberikan pembenaran ilmiah untuk standar yang lebih tinggi tersebut. Pembenaran ilmiah tersebut mengharuskan para negara anggota untuk melakukan penilaian risiko. ${ }^{23}$ Kewajiban mendasar yang diatur dalam SPS Agreement termasuk kewajiban yang berkaitan dengan

\footnotetext{
${ }^{20}$ Peter van den Bossche, Daniar Natakusumah dan Joseph Wira Koesnaidi., Loc.Cit.

${ }^{21}$ Eko Prilianto Sudradjat, Op. Cit., hlm. 11.

22 Ibid.

${ }^{23}$ Anais Kedgley Laidlaw, "Is it Better to be Safe than Sorry? The Cartagena Protocol versus The World Trade Organisation", Victoria University of Wellington Law Review, 2005, hlm. 446.
} 
analisa resiko, misalnya penilaian resiko dan manajemen risiko. Mengenai penilaian risiko, Pasal 5 ayat (1) dari SPS Agreement mensyaratkan bahwa negara anggota WTO harus memastikan tindakan SPS mereka agar didasarkan pada suatu penilaian ilmiah yang mengkaji risiko terhadap kehidupan atau kesehatan manusia, binatang atau tumbuhan. Para negara anggota WTO hanya boleh menerapkan tindakan SPS jika risiko tersebut ada. Mengenai manajemen risiko, SPS Agreement terutama mensyaratkan bahwa negara anggota WTO harus:24

a. Memastikan bahwa tindakan SPS tersebut tidaklah lebih menghambat perdagangan dari apa yang diperlukan untuk mencapai tingkat perlindungan yang seharusnya; (Pasal 5 ayat (6) SPS Agreement) dan

b. Menghindari perbedaan secara sepihak atau tidak mendasar mengenai tingkatan perlindungan yang seharusnya dalam situasi yang berbeda, jika perbedaan ini akan mengarah kepada diskriminasi atau hambatan terselubung terhadap perdagangan. (Pasal 5 ayat (5) SPS Agreement).

Jika bukti ilmiah yang dimiliki untuk melakukan sebuah penilaian resiko tidak mencukupi, Pasal 5 ayat (7) SPS Agreement memperbolehkan para negara anggota WTO untuk menerapkan tindakan SPS sementara dalam kondisi tertentu. Dengan cara ini, SPS Agreement memasukkan prinsip pencegahan atau kehatihatian (precautionary). ${ }^{25}$ Terkait dengan definisi prinsip kehati-hatian terdapat dalam berbagai kesepakatan internasional. Salah satu definisi prinsip kehati-hatian dimuat dalam Pasal 15 Deklarasi Rio, sebagai berikut berikut: "Where there are threats of serious or irreversible damage, lack of full scientific certainty shall not be used as a reason for postponing cost-efective measures to prevent environmental degradation". Berdasarkan prinsip ini, jika ada suatu ancaman atau suatu kerusakan yang sangat serius, kurangnya kepastian dalam ilmu pengetahuan tidak dapat dijadikan alasan untuk menunda suatu tindakan yang efektif untuk mencegah kerusakan lingkungan. Namun demikian, berdasarkan prinsip kehati-hatian suatu tindakan akan diambil jika terdapat suatu bukti ilmiah yang memadai, sehingga tanpa

${ }^{24}$ Peter van den Bossche, Daniar Natakusumah dan Joseph Wira Koesnaidi., Op. Cit., hlm. 86-87.

${ }^{25}$ Ibid., hlm. 87. 
adanya suatu bukti ilmiah yang memadai tidak akan dilakukan suatu tindakan tertentu. ${ }^{26}$

Secara garis besar ada beberapa hal yang harus dipatuhi oleh negara anggota dalam hal membentuk peraturan untuk perlindungan terhadap kesehatan dan kehidupan manusia, hewan dan tumbuhan di dalam wilayahnya, hal-hal utama yang di atur di dalam SPS Agreement dalam hal ini adalah:27

a. Scientific Validation (Kepastian secara ilmiah)

Pasal 2 SPS Agreement mengatur bahwa anggota WTO memiliki hak untuk mengadopsi tindakan SPS untuk memenuhi tingkat kesehatan yang diatur didalam wilayahnya. Hal tersebut disebut juga ALOP (Appropriate Level of Protection) atau tingkat resiko yang dapat diterima. Dalam menerapkan hal tersebut maka negara anggota wajib mendasarkan penilaian kesehatan akan suatu produk dengan menggunakan prinsip ilmiah, sehingga hasilnya dapat dibuktikan secara ilmiah, pengecualian atas hal ini adalah dengan menggunakan penelitian ilmiah atas resiko.

b. Harmonization (Harmonisasi) - Mendasarkan tindakan yang dilakukan sesuai dengan standar internasional

Pasal 3 SPS Agreement menyebutkan bahwa SPS Agreement mendorong negara anggota untuk mendasarkan tindakan yang dilakukan sesuai dengan standar, panduan, dan rekomendasi internasional dalam hal tindakan tersebut diatur secara internasional. Hal ini memfasilitasi penyeragaman atau pembentukan, pengakuan dan penerapan dari ketentuan SPS, dari negara anggota yang berbeda. Dengan penyeragaman dengan standar internasional, ketahanan pangan dan perlindungan kesehatan atas hewan serta tanaman akan terwujud dengan tanpa melakukan pembatasan perdagangan yang berlebihan.

c. Pelaksanaan Tindakan SPS dengan Tidak Menggunakan Standar Internasional Berdasarkan Pasal 3 dan Pasal 5 SPS Agreement, negara anggota dapat menerapkan tindakan SPS yang lebih ketat daripada standar internasional terkait atau menerapkan tindakan SPS sendiri, karena tidak adanya standar internasional atas tindakan tersebut, tindakan tersebut dibatas pada:

- Harus didasarkan pada penelitian ilmiah atas resiko;

- Dipergunakan secara terus menerus atas kasus yang sama;

- Tidak membatasi perdagangan lebih dari yang diperlukan.

d. Consistency

Persyaratan konsistensi berdasarkan Pasal 5 ayat (5) SPS Agreement adalah negara anggota harus menghindari perbedaan yang tidak dapat dipertanggungjawabkan yang mengakibatkan adanya diskriminasi atau pembatasan perdagangan internasional yang terselubung.

\footnotetext{
26 Sri Wartini, Op.Cit., hlm. 297.

${ }^{27}$ Eko Prilianto Sudradjat, Op.Cit., hlm. 13-14.
} 
e. Pembatasan yang sesuai (Not More Trade Restrictive than Necessary) Pasal 5 ayat (6) SPS Agreement, mensyarakatkan negara anggota untuk menerapkan tindakan yang tidak melebihi pembatasan perdagangan yang diperlukan untuk mendapatkan tingkat perlindungan yang sesuai. Hal ini menunjukan ketika negara anggota menggunakan alternatif tindakan (tidak menggunakan standar internasional) untuk mencapai tingkat perlindungan yang tepat, pemerintah didalam negara anggota harus menerapkan tindakan pembatasan perdagangan yang tepat (tidak berlebihan).

f. Tindakan Pendahuluan (Provisional Measures)

Tindakan pendahuluan di atur di dalam Pasal 5 ayat (7) SPS Agreement yang memperbolehkan pelaksanaan tindakan pendahuluan ketika belum adanya bukti ilmiah yang mencukupi untuk menetapkan keputusan akhir atas keamanan dari suatu barang atau proses. Dalam hal ini di atur dalam melakukan tindakan pendahuluan maka negara anggota diwajibkan untuk mencari informasi tambahan yang diperlukan untuk penelitian resiko yang lebih obyektif dan mengevaluasi kembali dalam jangka waktu yang cukup tindakan SPS yang telah dilaksanakan.

g. Keseimbangan - ketika tindakan yang berbeda satu sama lain menghasilkan tingkat perlindungan kesehatan yang sama

Pasal 4 SPS Agreement mengatur bahwa dimungkinkan melakukan beberapa tindakan SPS yang menghasilkan tingkat pengamanan yang sama. Berdasarkan atas hal tersebut negara yang mengimpor produk berkewajiban untuk melaksanakan tindakan tersebut bilamana tindakan tersebut akan mencapai tingkat perlindungan yang sama.

h. Regionalisasi - Menyesuaikan tindakan SPS dengan kondisi regional

Hal tersebut terkait dengan wilayah, dimana negara anggota yang akan melakukan tindakan SPS, diwajibkan menelaah terlebih dahulu keadaan didalam wilayah tersebut dalam hal hanya beberapa daerah yang terbukti produknya membahayakan, bilamana hasil penelaahan tersebut hanya beberapa wilayah yang terbukti memproduksi barang yang mengandung ancaman bagi kesehatan

i. Kontrol, Inspeksi dan Prosedur Persetujuan

Annex C dari SPS Agreement menyaratkan dalam prosedur uji coba dan inspeksi untuk menerapkan tindakan SPS tidak menjadi hambatan atas perdagangan internasional.

Berdasarkan pembahasan diatas maka dapat dilihat bahwa SPS Agreement mencoba membatasi tindakan negara dalam melakuan tindakan SPS. Tindakan SPS merupakan tindakan yang dapat menjadi hambatan bagi pelaksanaan perdagangan bebas, akan tetapi sekaligus merupakan kewajiban politik dari pemerintah yang berkuasa untuk melindungi kesehatan warga negaranya, berdasarkan atas hal tersebut maka dibentuklah SPS Agreement, yang mengecualikan pelaksanaan 
hambatan perdagangan dalam hal perlindungan kesehatan manusia, hewan dan tanaman di dalam wilayahnya. Tindakan atau aturan yang dibentuk harus sesuai dengan ketentuan yang terdapat didalam SPS Agreement. ${ }^{28}$

Kemudian terkait pelaksanaannya, SPS Agreement dijalankan oleh Komite Ketentuan Sanitasi dan Fitosanitasi (The SPS Committee, Komite SPS). Komite SPS adalah forum konsultasi dimana anggota WTO secara reguler bertemu untuk berdiskusi tentang ketentuan SPS dan efeknya terhadap perdagangan, mengawasi pelaksanaan SPS Agreement, dan mencari cara untuk menghindari terjadinya potensi perbedaan pendapat. Para anggota WTO memperoleh manfaat dengan berpartisipasi aktif dalam Komite SPS. Komite ini mempunyai berbagai aktivitas untuk membantu anggota dalam mengimplementasikan SPS Agreement. ${ }^{29}$

\section{Kasus Terkait SPS Agreement yang Melibatkan Indonesia}

Indonesia, sebagaimana telah dibahas sebelumnya, pernah setidaknya dua kali berperkara di WTO terkait dengan SPS Agreement. Akan tetapi, sejauh ini Indonesia selalu menjadi pihak yang digugat dan belum pernah menggugat negara anggota WTO yang lain terkait dengan SPS Agreement. Dua kasus di WTO yang melibatkan Indonesia terkait dengan SPS Agreement tersebut adalah kasus yang terdaftar di Badan Penyelesaian Sengketa WTO dengan nomor DS484 dan DS506. Akan tetapi, dalam tulisan ini akan lebih fokus membahas kasus pertama, yaitu kasus dengan nomor DS484 dan judul "Indonesia - Measures Concerning the Importation of Chicken Meat and Chicken Products". Kasus tersebut diajukan ke WTO oleh Brazil selaku pihak penggugat terhadap Indonesia selaku pihak tergugat.

Kasus tersebut mulai diajukan ke WTO oleh Brazil pada 16 Oktober 2014 dimana Brazil mengajukan permohonan untuk konsultasi dengan Indonesia. Konsultasi tersebut terkait dengan tindakan tertentu yang dikenakan oleh Indonesia terhadap impor daging ayam dan produk turunannya. Brazil mengklaim bahwa tindakan-tindakan tersebut tidak sejalan dengan beberapa ketentuan di WTO. Terkait dengan SPS Agreement, Brazil mengklaim Indonesia menerapkan tindakan-tindakan yang tidak sejalan dengan Articles 2.2, 2.3, 3.1, 5, 5.1, 5.2, 5.5, 5.6,

\footnotetext{
28 Ibid., hlm. 15.

${ }^{29}$ Departemen Pertanian, Perikanan, dan Kehutanan Australia, Op. Cit., hlm. 5-6.
} 
8 dan Annex C of the SPS Agreement. Pada 31 Oktober 2014, Australia, Selandia Baru,

Taiwan dan Amerika Serikat mengajukan permohonan untuk bergabung dalam konsultasi tersebut. Selanjutnya pada 3 November 2014, Uni Eropa juga mengajukan permohonan untuk bergabung dalam konsultasi. Menindak lanjuti permohonan-permohonan tersebut, Indonesia menginformasikan kepada Dispute Settlement Body (Badan Penyelesaian Sengketa, DSB) bahwa mereka menerima permohonan-permohonan tersebut. ${ }^{30}$

Menurut Brazil dalam permohonan konsultasinya, ada beberapa peraturan di Indonesia yang tidak sesuai dengan ketentuan-ketentuan yang diatur oleh WTO, yaitu: ${ }^{31}$

a. Undang-Undang Nomor 7 Tahun 2014 tentang Perdagangan (UU Perdagangan);

b. Undang-Undang Nomor 18 Tahun 2009 tentang Peternakan Dan Kesehatan Hewan;

c. Peraturan Menteri Pertanian Nomor 84 Tahun 2013 tentang Pemasukan Karkas, Daging, Jeroan, dan/atau Olahannya ke dalam Wilayah Negara Republik Indonesia, yang diamandemen dengan Peraturan Menteri Pertanian Nomor 96 Tahun 2013 dan Peraturan Menteri Pertanian Nomor 110 Tahun 2014 (Permentan 84/2013);

d. Peraturan Menteri Perdagangan Nomor 46 Tahun 2013 tentang Ketentuan Impor dan Ekspor Hewan dan Produk Hewan, yang diamandemen dengan Peraturan Menteri Perdagangan Nomor 57 Tahun 2013 dan Peraturan Menteri Perdagangan Nomor 17 Tahun 2014 (Permendag 46/13);

e. Peraturan Menteri Perdagangan Nomor 83 Tahun 2012 tentang Ketentuan Impor Produk Tertentu, yang diamandemen dengan Peraturan Menteri Perdagangan Nomor 61 Tahun 2013 (Permendag 83/2012);

f. Peraturan Menteri Perdagangan Nomor 27 Tahun 2012 tentang Ketentuan Angka Pengenal Importir, yang diamandemen dengan Peraturan Menteri Perdagangan Nomor 59 Tahun 2012 dan Peraturan Menteri Perdagangan Nomor 84 Tahun 2012 (Permendag 27/2012);

g. Peraturan Menteri Perdagangan Nomor 54 Tahun 2009 tentang Ketentuan Umum di Bidang Impor (Permendag 54/2009);

h. Keputusan Menteri Keuangan Nomor 454 Tahun 2002 tentang Registrasi Importir (Kepmenkeu 454/2002).

30 World Trade Organization, "DS484: Indonesia — Measures Concerning the Importation of Chicken Meat and Chicken Products”, https://www.wto.org/english/tratop_e/dispu_e/cases_e/ds484_e.htm, diakses pada 30 Juli 2017.

${ }^{31}$ Dokumen Permohonan Konsultasi WTO No. WT/DS484/1, hlm. 2-3. 
Brazil kemudian mengadakan konsultasi dengan Indonesia pada 15 dan 16 Desember 2014. Konsultasi tersebut pada akhirnya tidak dapat menyelesaikan sengketa. ${ }^{32}$ Pada 15 Oktober 2015, Brazil mengajukan permohonan pembentukan Panel. Kemudian saat pertemuan 28 Oktober 2015, Badan Penyelesaian Sengketa WTO (DSB) menangguhkan pembentukan Panel. Pada pertemuan DSB berikutnya tanggal 25 November 2015, Indonesia mengajukan keberatan terhadap pembentukan Panel karena adanya sebuah corrigendum (ralat) terhadap permohonan pembentukan Panel yang telah diedarkan atas permintaan dari Brazil. Atas keberatan Indonesia tersebut, Brazil meminta agar pembentukan Panel ditangguhkan ke pertemuan selanjutnya. Dengan tidak adanya keberatan dari Brazil, DSB menangguhkan pembentukan Panel. ${ }^{33}$

Berdasarkan permohonan pembentukan Panel yang diajukan, secara garis besar keberatan Brazil dapat dibagi menjadi menjadi dua, yaitu Pertama mengenai adanya pemberlakuan larangan umum terhadap impor daging ayam dan produk turunannya oleh Indonesia yang dianggap tidak sesuai dengan ketentuan WTO. Kedua mengenai penerapan pembatasan dan larangan khusus terhadap impor daging ayam dan produk turunannya. ${ }^{34}$ Terkait keberatan yang pertama, ada beberapa aturan di Indonesia yang menjadi keberatan bagi Brazil, yaitu:35
a. Pasal 14, 15, 36, 55 dan 56 Undang-Undang Nomor 18 Tahun 2012 tentang Pangan (UU Pangan);
b. Lampiran II Permendag 46/13;
c. Pasal 32 ayat (2) dan Lampiran II Peraturan Menteri Pertanian Nomor 139 Tahun 2014 tentang Pemasukan Karkas, Daging, dan/atau Olahannya ke dalam Wilayah Negara Republik Indonesia (Permentan 139/2014);
d. Pasal 26 UU Perdagangan; dan
e. Undang-Undang Nomor 33 Tahun 2014 tentang Jaminan Produk Halal.

Aturan-aturan tersebut dianggap Brazil tidak konsisten atau tidak sesuai dengan beberapa ketentuan yang ada di WTO termasuk salah satunya ketentuan dalam SPS Agreement. Terkait dengan SPS Agreement, di antara aturan-aturan

\footnotetext{
32 Dokumen Permohonan Pembentukan Panel WTO oleh Brazil No. WT/DS484/8, hlm. 1.

33 World Trade Organization, Loc.Cit.

${ }^{34}$ Dokumen Permohonan Pembentukan Panel WTO oleh Brazil No. WT/DS484/8, Loc.Cit

35 Ibid., hlm. 2-3.
} 
yang diterapkan Indonesia tersebut ada yang dianggap oleh Brazil bertentangan dengan ketentuan-ketentuan SPS Agreement seperti berikut ini: ${ }^{36}$

a. Pasal 2.2 SPS Agreement, karena tindakan Indonesia diterapkan di luar batas yang diperlukan untuk melindungi kehidupan manusia dan hewan, tidak didasarkan pada prinsip ilmiah, dan dipertahankan tanpa bukti ilmiah yang memadai;

b. Pasal 3.1, 3.2 dan 3.3 SPS Agreement, karena tindakan Indonesia tidak sesuai atau tidak didasarkan pada standar internasional, pedoman, atau rekomendasi, dan tanpa pembenaran ilmiah, tingkat keamanan sanitasi dan fitosanitasi yang lebih tinggi daripada yang dapat dicapai dengan tindakan berdasarkan standar internasional yang relevan, pedoman atau rekomendasi;

c. Pasal 5.1, 5.2 dan 5.4 SPS Agreement, karena tindakan-tindakan tersebut membatasi impor produk tanpa penilaian risiko yang tepat;

d. Pasal 5.6 SPS Agreement, karena Indonesia mempertahankan tindakan sanitasi yang lebih membatasi perdagangan daripada yang diminta untuk mencapai tingkat perlindungan yang sesuai;

e. Pasal 8 dan Annex C SPS Agreement, karena penundaan yang tidak semestinya menghambat penyelesaian prosedur kontrol, inspeksi dan persetujuan terhadap impor daging ayam dan produk ayam ke Indonesia;

Terkait keberatan yang kedua, setidaknya ada enam hal yang menjadi objek keberatan Brazil, yaitu: ${ }^{37}$

a. Indonesia mempertahankan tindakan-tindakan pembatasan dan larangan impor terhadap daging ayam dan produk turunannya yang mana tidak sesuai atau tidak didasarkan pada standar internasional.

b. Indonesia mempertahankan tindakan-tindakan yang lebih menghambat perdagangan daripada yang diminta untuk mencapai tingkat perlindungan yang sesuai;

c. Penundaan yang tidak sesuai dengan prosedur persetujuan;

d. Indonesia mempertahankan tindakan-tindakan yang mendiskriminasikan impor daging ayam dan produk turunannya;

e. Pembatasan Impor daging ayam dan produk turunannya melalui rezim Lisensi Impor Indonesia;

f. Tidak konsisten terhadap syarat-syarat transparansi WTO;

Pada pertemuan tanggal 3 Desember 2015, DSB membentuk Panel. Argentina, Australia, Kanada, Chili, Cina, Uni Eropa, India, Jepang, Korea, Selandia Baru,

${ }^{36}$ Ibid., hlm. 3.

${ }^{37}$ Ibid., hlm. 4-9. 
Norwegia, Oman, Paraguay, Qatar, Rusia, Thailand, Cina Taipei (Taiwan), Vietnam, dan Amerika Serikat bergabung sebagai pihak ketiga. Pada 22 Februari 2016, Brazil memohon kepada Direktur Jenderal WTO untuk menyusun Panel. Permohonan tersebut kemudian ditindak lanjuti oleh Direktur Jenderal WTO dengan menyusunkan Panel pada tanggal 3 Maret 2016.

Pada 31 Agustus 2016, Ketua Panel menginformasikan kepada DSB bahwa Panel diharapkan untuk mengeluarkan laporan akhirnya kepada para pihak pada awal April 2017, sesuai dengan jadwal yang diadopsi setelah berkonsultasi dengan para pihak. Kemudian pada tanggal 31 Maret 2017, Ketua Panel menginformasikan kepada DSB bahwa dikarenakan kompleksitas sengketa tersebut, Panel diharapkan dapat mengeluarkan laporan akhirnya kepada para pihak pada awal Mei 2017, sesuai dengan jadwal revisi yang diadopsi setelah berkonsultasi dengan para pihak. ${ }^{38}$ Akan tetapi, menurut ringkasan serta dokumen kasus DS484 yang ada di situs resmi WTO, dalam kasus tersebut hingga kini belum dikeluarkan laporan akhir oleh Panel. Ringkasan kasus terakhir diperbarui pada 20 April 2017, sedangkan dokumen terakhir diperbarui pada 3 April 2017, yaitu dokumen komunikasi dari Ketua Panel kepada DSB.

Berdasarkan kasus tersebut, meskipun Indonesia telah digugat oleh Brazil di WTO, tetapi keberatan-keberatan yang diajukan oleh Brazil sebenarnya dapat dimentahkan oleh Indonesia apabila Indonesia mampu membuktikan mengapa aturan-aturan yang digugat tersebut tetap diterapkan oleh Indonesia. Seperti misalnya mengenai penerapan daftar positif yang berisi daftar produk-produk yang boleh diimpor. Daftar tersebut diterapkan tentu untuk menjamin agar produkproduk yang diimpor dapat memenuhi standar yang aman bagi masyarakat dan memberikan perlindungan kepada konsumen nantinya, bukan untuk mendiskriminasikan produk tertentu. Kemudian ada juga mengenai kehalalan suatu produk. Sebagaimana kita ketahui bahwa mayoritas masyarakat Indonesia adalah muslim. Sangat penting bagi pemerintah untuk menjamin halal tidaknya suatu produk yang diimpor tersebut. Meskipun, permasalahan kehalalan suatu produk yang jadi keberatan Brazil tersebut lebih kepada persoalan label atau lisensi.

38 World Trade Organization, Loc.Cit. 
Mengenai tanggapan resmi Indonesia dalam forum panel penyelesaian sengketa tersebut, tidak dapat ditemukan dokumennya dalam situs resmi WTO. Sejauh ini dokumen yang tersedia di situs resmi WTO hanya sebatas sampai pada komunikasi Ketua Panel terkait tenggat waktu penyelesaian sengketa tersebut. Akan tetapi, hingga kini, yang mana telah melewati tenggat yang diharapkan tersebut, masih juga belum dapat ditemukan dokumen lanjutan dari sengketa tersebut. Oleh karena itu, masih belum dapat dilihat bagaimana argumen resmi Indonesia dalam menanggapi gugatan dari Brazil tersebut.

Berdasarkan hal-hal di atas, dapat dilihat bahwa dampak dari adanya SPS Agreement terhadap perdagangan di Indonesia adalah Indonesia dapat menerapkan aturan yang dapat lebih melindungi warganya dari risiko kesehatan yang mungkin timbul dari adanya impor produk tertentu terutama soal makanan. Penerapan tersebut dapat dilakukan tanpa perlu khawatir melanggar prinsip bebas hambatan yang diterapkan WTO asalkan aturan yang diterapkan sesuai dengan ketentuan yang ada dalam SPS Agreement. Meskipun Indonesia telah dua kali digugat, yang mana keduanya dilakukan oleh Brazil dan salah satunya telah sampai pada tahap panel, tetapi hal tersebut tidak terlalu mempengaruhi perdagangan di Indonesia. Tindakan-tindakan yang dilakukan Indonesia, terutama yang terkait dengan kasus yang telah dibahas di atas, lebih kepada mewujudkan keamanan pangan dan memberikan perlindungan bagi masyarakat, bukan untuk mendiskriminasi produk tertentu dan menghambat perdagangan yang ada.

\section{Penutup}

Berdasarkan pembahasan yang telah diuraikan di atas, maka dapat ditarik kesimpulan sebagai berikut: Pertama, mengenai apakah adanya SPS Agreement tersebut justru menjadi hambatan dalam perdagangan. Adanya SPS Agreement memberikan hak bagi para negara anggota WTO untuk dapat melakukan suatu Tindakan SPS. Tindakan tersebut merupakan tindakan yang dapat menjadi hambatan bagi pelaksanaan perdagangan bebas, akan tetapi sekaligus merupakan kewajiban politik dari pemerintah yang berkuasa untuk melindungi kesehatan 
warga negaranya. Berdasarkan atas hal tersebut maka dibentuklah SPS Agreement, yang mengecualikan pelaksanaan hambatan perdagangan dalam hal perlindungan kesehatan manusia, hewan dan tanaman didalam wilayahnya. Tindakan atau aturan yang dibentuk harus sesuai dengan ketentuan yang terdapat di dalam SPS Agreement. Agar pelaksanaan SPS Agreement dapat sesuai ketentuan yang ada serta dapat diawasi, pelaksanaannya dijalankan oleh Komite Ketentuan Sanitasi dan Fitosanitasi (the SPS Committee, Komite SPS). Komite SPS adalah forum konsultasi dimana anggota WTO secara reguler bertemu untuk berdiskusi tentang ketentuan SPS dan efeknya terhadap perdagangan, mengawasi pelaksanaan SPS Agreement, dan mencari cara untuk menghindari terjadinya potensi perbedaan pendapat. Komite ini mempunyai berbagai aktivitas untuk membantu anggota dalam mengimplementasikan SPS Agreement.

Kedua, mengenai bagaimana dampak SPS Agreement terhadap perdagangan di Indonesia. Adanya SPS Agreement membuat Indonesia dapat menerapkan aturan yang lebih melindungi warganya dari risiko kesehatan yang mungkin timbul dari adanya impor produk tertentu terutama makanan. Hal tersebut dapat dilakukan tanpa perlu khawatir melanggar prinsip bebas hambatan yang diterapkan WTO asalkan aturan yang diterapkan sesuai dengan ketentuan yang ada dalam SPS Agreement. Meskipun Indonesia telah dua kali digugat, yang mana keduanya dilakukan oleh Brazil dan salah satunya telah sampai pada tahap panel, tetapi hal tersebut tidak terlalu mempengaruhi perdagangan di Indonesia. Tindakan-tindakan yang dilakukan Indonesia, terutama yang terkait dengan kasus yang telah dibahas di atas, lebih kepada mewujudkan keamanan pangan dan memberikan perlindungan bagi masyarakat, bukan untuk mendiskriminasi produk tertentu dan menghambat perdagangan yang ada.

Berdasarkan kesimpulan-kesimpulan di atas, maka saran yang dapat diberikan adalah Indonesia diharapkan dapat memanfaatkan adanya SPS Agreement tersebut untuk tujuan memberikan perlindungan warganya dari risiko kesehatan yang mungkin timbul dari kegiatan impor suatu produk terutama terkait dengan makanan. Indonesia tidak perlu khawatir melanggar prinsip bebas hambatan WTO asalkan ketentuan yang diterapkan tetap sejalan dengan SPS Agreement. 


\section{Daftar Pustaka}

\section{Buku}

Fajar, Mukti dan Yulianto Achmad, Dualisme Penelitian Hukum: Normatif E Empiris, Pustaka Pelajar, Yogyakarta, 2010.

Ibrahim, Johnny, Teori dan Metodologi Penelitian Hukum Normatif, Bayumedia Publishing, Malang, 2008.

Kartadjoemena, H.S., GATT, WTO dan Hasil Uruguay Round, UI Press, Jakarta, 2007. van den Bossche, Peter, Daniar Natakusumah dan Joseph Wira Koesnaidi., Pengantar Hukum WTO (World Trade Organization), Yayasan Obor Indonesia, Jakarta, 2010.

van den Bossche, Peter dan Werner Zdouc, The Law and Policy of the World Trade Organization: Text, Cases and Material, Cambridge University Press, Cambridge, 2017.

\section{Jurnal}

Kennedy, Kevin C., "Resolving International Sanitary and Phytosanitary Disputes in The WTO: Lessons and Future Directions", Food and Drug Law Journal, Vol. 55, 2000.

Laidlaw, Anais Kedgley, "Is it Better to be Safe than Sorry? The Cartagena Protocol versus The World Trade Organisation", Victoria University of Wellington Law Review, 2005.

Risnain, Muh., "Politik Hukum Perlindungan Industri dalam Negeri Indonesia dalam Menghadapi Perdagangan Bebas", Fiat Justisia Jurnal Ilmu Hukum, Vol. 5 No. 3, 2011.

Sudradjat, Eko Prilianto, "Penerapan WTO-Agreement on The Application of Sanitary and Phytosanitary Measures: Analisis Tentang Penerapan Public Health Security And Bioterrorism Preparedness And Response Act Of 2002 oleh Amerika Serikat", Jendela Informasi Hukum Bidang Perdagangan, 2012

Wartini, Sri, "Implementasi Prinsip Kehati-hatian dalam Sanitary and Phythosanitary Agreemant, Studi Kasus: Keputusan Appellate Body WTO Dalam Kasus Hormone Beef Antara Uni Eropa Dengan Amerika Serikat", Jurnal Hukum, Vol. 14 No. 2, 2007.

\section{Peraturan Perundang-Undangan, Dokumen, dan Perjanjian Internasional}

Agreement on The Application of Sanitary and Phytosanitary Measures Dokumen Permohonan Konsultasi WTO No. WT/DS484/1

Dokumen Permohonan Pembentukan Panel WTO oleh Brazil No. WT/DS484/8 Dokumen Permohonan Konsultasi WTO No. WT/DS506/1 


\section{Internet}

Departemen Pertanian, Perikanan, dan Kehutanan Australia, "Kesepakatan Organisasi Perdagangan Dunia (WTO) tentang Sanitari dan Fitosanitari", http:/ / www.agriculture.gov.au/SiteCollectionDocuments/languages/in donesian/piaph/sp s_booklet_bahasa.pdf

Ika, Aprillia, “Brasil Gugat Indonesia Terkait Syarat Importasi Daging dan Produk Ayam yang Halal", http://ekonomi.kompas.com/read/2016/10/15/ 100000826/brasil.gugat.indonesia.terkait.syarat.importasi.daging.dan.pro duk.ayam.yang.halal.

World Trade Organization, "DS484 : Indonesia - Measures Concerning the Importation of Chicken Meat and Chicken Products", https://www.wto.org/english/tratop_e/dispu_e/cases_e/ds484_e.htm 